\title{
Chemical investigation and quality of urban dew collections with dust precipitates
}

\section{Odeh, Issam}

\author{
2017-05
}

Odeh , I , Arar , S , Al-Hunaiti , A , Sa'aydeh , H , Hammad, G, Duplissy , J , Vuollekoski , H , Korpela , A , Petäjä , T , Kulmala , M \& Hussein , T 2017 , ' Chemical investigation and quality of urban dew collections with dust precipitates ' , Environmental Science and Pollution Research , vol. 24 , no. 13 , pp. 12312-12318 . https://doi.org/10.1007/s11356-017-8870-3

http://hdl.handle.net/10138/307289

https://doi.org/10.1007/s11356-017-8870-3

unspecified

acceptedVersion

Downloaded from Helda, University of Helsinki institutional repository.

This is an electronic reprint of the original article.

This reprint may differ from the original in pagination and typographic detail.

Please cite the original version. 


\title{
Chemical Investigation and Quality of Urban Dew Collections with Dust Precipitates
}

\author{
Issam Odeh ${ }^{1}$, Sharif Arar ${ }^{2(*)}$, Afnan Al-Hunaiti ${ }^{3(\dagger)}$, Hiyam Sa' aydeh ${ }^{4}$, Ghada Hammad ${ }^{4}$, Jonathan \\ Duplissy ${ }^{5,6}$, Henri Vuollekoski ${ }^{6}$, Antti Korpela ${ }^{7}$, Tuukka Petäjä ${ }^{6}$, Markku Kulmala ${ }^{6}$, Tareq Hussein ${ }^{6,8}$ \\ ${ }^{1}$ Al Zaytoonah University of Jordan, Department of Basic Sciences, P.O. Box 130, Amman 11733, Jordan \\ ${ }^{2}$ The University of Jordan, Department of Chemistry, Amman 11942, Jordan \\ ${ }^{3}$ Petra University, Department of Chemistry, Amman 11196, Jordan \\ ${ }^{4}$ Water Authority of Jordan, Laboratories and Quality Affairs, Amman 11183, Jordan \\ ${ }^{5}$ Helsinki Institute of Physics, P. O. Box 64, FI-00014 UHEL, Helsinki, Finland \\ ${ }^{6}$ University of Helsinki, Department of Physics, P. O. Box 64, FI-00014 UHEL, Helsinki, Finland \\ ${ }^{7}$ VTT Technical Research Centre of Finland, Espoo, Finland, P.O. Box 1000, FI-02044 \\ ${ }^{8}$ The University of Jordan, Department of Physics, Amman 11942, Jordan
}

\begin{abstract}
The quality and chemical composition of urban dew collections with dust precipitates without pre- cleaning of the collecting surface WSF (White Standard Foil) were investigated for 20 collected samples with collected volumes ranging from $22 \mathrm{ml}$ to $230 \mathrm{ml}$. The collection period was from March to July 2015 at an urban area, Jubaiha, which is located in the northern part of the capital city Amman, Jordan. The obtained results indicated the predominance of $\mathrm{Ca}^{2+}$ and $\mathrm{SO}_{4}{ }^{2-}$ ions (ratio 2.2:1) that originated from Saharan soil dust; where the collected samples were alkaline (mean $\mathrm{pH}=7.35$ ) with high mineralization $(429.22 \mathrm{mg} / \mathrm{L})$ exceeding the previously reported dew values in Amman-Jordan. A relocation of $\mathrm{NaCl}$ and to a less extent $\mathrm{Mg}^{2+}$ from sea to land by Saharan wind is indicated by the percent sea-salt fraction calculations (over 100 and 52 respectively). The collected samples exhibited high total organic carbon (TOC) values ranging from 11.86 to $74.60 \mathrm{mg} / \mathrm{L}$, presence of particulate settled material with turbidity ranging from 20.10 to $520.00 \mathrm{NTU}$, and presence of undesired elements like boron (mean $=1.48 \mathrm{mg} / \mathrm{L}$ ) that made it different in properties from other dew water collections at clean surfaces, and exceeding the standard limits for drinking water for these parameters set by Jordanian Drinking Water standards (JS286/1997)/WHO standard. The quality of this water is more close to that for raw or agricultural water but if it is meant to be used as potable source of water at least sand and activated charcoal filters are needed to purify it.
\end{abstract}

Keywords: dew, dust precipitate, mineralization, alkalinity, urban, TOC, water quality

\footnotetext{
* Corresponding author, Tel: +962-6-5355000 Ext: 22175; Fax: +962-6-5300253

E-mail address: s.arar@ju.edu.jo

${ }^{\dagger}$ Corresponding author, Tel: +962-6-5799555; Fax: +962-6-5715570

E-mail address: aalhuniti@uop.edu.jo
} 


\section{Introduction}

Dew is a phenomenon where water condenses on substrates from humid air; it can be considered from different point of views (Beysens 1995). From a meteorological point of view, dew is defined as water vapor condensation on submicron particles (condensation cloud nuclei, $\mathrm{CCN}$ ) forming rain or on large surfaces such as plant leaves. From hydrological point of view, it can be a significant source of water to be used in agriculture or even as fresh water for drinking. From a botanic point of view, dew participates in plants' exchange processes with the atmosphere.

From a physical point of view, dew is a phase transition phenomena in which a bulk homogeneous vapor phase (characterized by temperature and pressure) transforms into a liquid phase on a substrate, which is held at a lower temperature of the vapor phase. The physical properties of the substrate are one of the most important parameters to be considered in enhancing dew formation. Without going into details, dew is formed via two main steps: (1) nucleation of a liquid phase forming a droplet on an obstacle (particle, surface, etc.) and (2) growth of the droplet at the expense of the surrounding atmosphere ( Beysens 1995). As later postulated by Beysens (2006), the presence of a substrate that geometrically constrains the growth is the origin of the peculiarities and richness of the phenomenon. A key point is the drop interaction through drop fusion or coalescence, which leads to scaling in the growth and gives universality to the process.

Dew has advantages and disadvantages. Although the amount of water collected during dew formation is smaller than that collected from rain, it can be a significant source of water for plants, animals, and insects in semi-arid regions (Moffett 1985; Degen et al. 1992; Zangvil 1996; Shachak et al. 2002; Beysens et al. 2007; Guadarrama - Cetina et al. 2014; Vuollekoski et al. 2015). Sometimes the harvested dew water amount might exceed that collected from rainfall (Agam and Berliner 2006). Dew water harvesting is not only a reasonable supply of water for agriculture but also as a source of drinking water (Lekouch et al. 2011; Beysens et al. 2006; Muselli et al. 2006; Alnaser and Barakat 2000). Dew formation on plant leaves might accommodates fungus spores and might damage the plants (Pedro and Gillespie 1982; Morin et al. 1993; Zhang and Watson 1997). The formation of dew on greenhouses lowers the light transmission that, in turn, lowers the yield of agricultural production; a similar negative impact has been found when dew affects the soil-surface albedo, which in turn affects the solar radiation balance over crops (Menenti et al. 1989; Minnis et al. 1997).

Besides the harvested amount, the chemical composition quality of dew water is also an important issue in order to consider it usable as a source of drinking water (Galek et al. 2015; Gałek et al. 2012; Lekouch et al. 2010; Polkowska et al. 2008; Okochi et al. 2005; Jiries 2001; Wagner et al. 1992; Foster et al. 1990; Yaalon and Ganor 1968). Some research has been going on in Jordan about the quality of different water resources; however, most of that research has been focused on rain water (Jaradat et al. 1999; Al-Momani et al. 2000) and very few studies was focused on dew water (Jiries 2001). Therefore, we conducted an intensive measurement campaign to harvest dew water nearby a major road at an urban site (northern part of Amman, Jordan). We intended in this study to collect the dew water without pre-treatment or cleaning of the collecting surface were dry deposition of dust is inevitable in addition to the wet deposition associated with the dew formation. This is contrary to what was previously done by Jiries (2001); or the wet deposition study where rain samples were collected immediately to avoid dust settling and filtered immediately through a $0.2-\mathrm{mm}$ pore size membrane (Jaradat et al. 1999). That was in purpose to investigate the chemical composition of the harvested dew water-dust precipitate quality as this was never reported in literature where assuming dew collection practices are done in areas where aerosols and dust are presence and collecting surfaces are not cleaned on daily basis. 


\section{Materials and methods}

\subsection{Dew water collection}

The dew water samples were collected during the period March - July 2015 at an urban area, Jubaiha, which is located in the northern part of the capital city Amman. The dew water was collected on a $1 \mathrm{~m}^{2}$ surface covered with a white hydrophilic foil (Nilsson et al. 1994) named white standard foil (WSF) recommended as standard for dew recovery by the International Organization for Dew Utilization (OPUR; http://www.opur.fr/). The surface itself was mounted on a metal frame that had a thermal insulator on the back facing the ground. The frame was inclined at $45^{\circ}$ and faced the north. The frame was equipped with a drain to guide dew water down to be collected inside a small container. During the nights of possible dew formation we monitored the condensation of water on the surface where also dust precipitation occurred due to the dusty weather. On hourly basis, the condensed water on the surface with accumulated dust was wiped down into the surface passing though the drain to be accumulated inside the small container. The dew water harvesting continued over night until the sunrise. Immediately after dew water harvesting was done, the amount of accumulated dew water in the small container was recorded and the dew water was emptied in small bottles $(30 \mathrm{ml}$ each) and stored in the fridge at $4^{\circ} \mathrm{C}$ after conducting urgent tests.

\subsection{Chemical analysis of dew water}

The $\mathrm{pH}$ values of the dew-dust aqueous samples were measured within 2 hours of receiving the samples at the chemistry department, The University of Jordan employing a pH-meter (Jenway $3510 \mathrm{pH}$ Meter, SM 4500- $\mathrm{H}^{+}$B). The Samples were kept at $4{ }^{\circ} \mathrm{C}$ and later on were sent to the Water Authority of Jordan (WAJ), Laboratories and Quality Affairs (ISO/IEC 17025 Accredited), Amman, Jordan for complete chemical testing. The chemical and physical analysis of the dew water samples at the WAJ included electrical conductivity (EC) employing EC meter (Thermo-Orion A150, SM 2510B), silica (UV-VIS-Carry spectrophotometer based on the Heteropoly Blue method), cations ( $\mathrm{Na}, \mathrm{K}, \mathrm{Mg}$, and $\mathrm{Ca}$ ) (Dionex ICS-1000, in house validated method), anions ( $\mathrm{Cl}, \mathrm{SO}_{4}, \mathrm{SO}_{3}$, and $\mathrm{NO}_{3}$ ) with ion chromatograph (Dionex ICS2000, SM 4110B), bicarbonate (SM 2320B) fluoride (Spectrophotometer (HACH-DR 5000), SM 4500-f SPADNS method), boron (UV-VIS-Carry spectrophotometer, Azomethine-H method), total organic carbon (TOC); TOC Analyzer (Tekmer-Phonix 8000), SM5310C Persulfate Ultraviolet Oxidation method. Total dissolved solids (TDS) (SM 1030 E), turbidity (Turb instrument model HACH 2100N, SM 2130 B), and hardness (SM 2340 B). The testing methods were according to Standard Methods for the Examination of Water and Wastewater ${ }^{(\mathrm{SM})}, 22^{\text {nd }}$ edition 2012.

\section{Results and discussion}

\section{1. $\mathrm{pH}$, bicarbonate, electrical conductivity (EC), and turbidity}

The average $\mathrm{pH}$ value for the tested dew-dust deposit samples was 7.35 and ranged from 6.90 and 8.17 (Table 1) indicating that most of the samples were neutral to slightly basic. The bicarbonate measured values ranged from $105 \mathrm{mg} / \mathrm{L}$ to 266.0 $\mathrm{mg} / \mathrm{L}$ with an average value of $181.5 \mathrm{mg} / \mathrm{L}$ (Table 1). Bicarbonate as a primary influential factor of the alkalinity that is correlated to the $\mathrm{pH}$ value (Thomas et al. 1960) is expected to be major compared to carbonate and hydroxide in samples with $\mathrm{pH}=6-8$; where in our case the $\mathrm{pH}$ of samples ranged from 6.90 and 8.17 as strong indication for the presence of bicarbonate and may be other basic constituents like borate, silicate, and phosphates (SM 2320 A). The electrical conductivity (EC) average value for tested samples was $613.17 \mu \mathrm{s} / \mathrm{cm}$ and ranged from $230 \mu \mathrm{s} / \mathrm{cm}-1305 \mu \mathrm{s} / \mathrm{cm}$. Collected dew-dust deposit samples in the $30 \mathrm{ml}$ glass vials showed remarkably two distinct layers when stagnant: aqueous upper layer and precipitate lower layer whereas milky appearance when shaken. The turbidity of these samples ranged from 
20.10 to 520.00 NTU with an average value of 192.23 indicating that all samples were turbid due to the presence of high amounts of particulate matter originating from dust deposition on collecting surfaces that were never cleaned prior to dew collection. These turbidity measured values for the dew collections with dust precipitate are considered high and exceeding the values for after rainfall from the White River in Muncie (Indiana) (Volk et al 2002) where they reached up to 135 NTU. The collection period from March to July witnessed many Saharan dust storms coming from south or south east carrying with them the soil and sand dust that is mainly composed of quartz with appreciable amounts of carbonates and soluble salts such as halite, illite, and gypsum (Singer et al. 1993). The measured dew-dust deposits values for the $\mathrm{pH}$, bicarbonate, and electrical conductivity (EC) were relatively higher than those previously reported results in Amman-Jordan regarding the dew (average $\mathrm{pH}=6.7$, average $\mathrm{EC}=128.7 \mu \mathrm{s} / \mathrm{cm}$ ) and wet deposition (average $\mathrm{pH}=6.15$, average $\mathrm{EC}=95.1 \mu \mathrm{s} / \mathrm{cm})($ Jiries 2001; Jaradat et al. 1999). The $\mathrm{pH}$ and EC results are compatible with reported data for a dew study in semi-arid city in Morocco laying northern of a sandy dusty desert (average $\mathrm{pH}=7.40$, average $\mathrm{EC}=725.25$ $\mu \mathrm{s} / \mathrm{cm}$ ) (Lekouch et al. 2011) where these high values are possibly due to co-occurrence of dry deposition on a wet surface. The higher alkalinity accompanied by a slight shift of the $\mathrm{pH}$ values above 7 for most of the tested dew-dust deposits samples is mainly due to the dissolution effect of dust precipitate coagulated particles basic components into the dew including $\mathrm{CaCO}_{3}$ (calcite), $\mathrm{MgCO}_{3}$ (dolomite) originating from Saharan soil dust (Ganor 1991); and to a second extent to the scavenging effect of dew formation (Takeuchi et al. 2002). The average total mineralization for the collected samples was as calculated (total mineralization $=0.7 \mathrm{EC}$ ) $429.22 \mathrm{mg} / \mathrm{L}$ which is much higher than that in dew results in AmmanJordan (Jiries 2001) which is $66.6 \mathrm{mg} / \mathrm{L}$ and comparable with mineralization value $(560 \mathrm{mg} / \mathrm{L})$ conducted in arid area in morocco (Lekouch et al. 2011) where dry climate dominates causing concentration of ions; indicating that our collected samples are alkaline with high mineralization due to dust pre-precipitation or co-precipitation with dew.

\subsection{Ionic concentrations}

Major dew-dust composition analysis data is summarized in Table 1, where average cationic species concentrations are arranged in descending order $\mathrm{Ca}^{2+}>\mathrm{Na}^{+}>\mathrm{Mg}^{2+}>\mathrm{K}^{+}$and for anionic species $\mathrm{HCO}_{3}>\mathrm{SO}_{4}{ }^{2-}>\mathrm{Cl}^{-}>$silicates $>\mathrm{NO}_{3}{ }^{-}$ $>$ metaborate $>\mathrm{F}^{-}$. The prevalence of $\mathrm{Ca}^{2+}$ followed by $\mathrm{Na}^{+}$is revealed more in Figure. 1 from the comparison of data of this study with dew water (Jiries 2001), where dust deposits (major calcite and minor dolomite, gypsum and illite) upon dissociation in dew-water contribute mainly $\mathrm{Ca}^{2+}$ with lower concentrations of $\mathrm{Na}^{+}$and $\mathrm{Mg}^{2+}$ (Ganor,1991). The originality of $\mathrm{Ca}^{2+}, \mathrm{Na}^{+}$and $\mathrm{Mg}^{2+}$ and other ions was cleared out from calculating the sea-salt fraction (SSF) and nonsea-salt fraction (NSSF) (Keene et al. 1986) as demonstrated by eq(1) and eq (2).

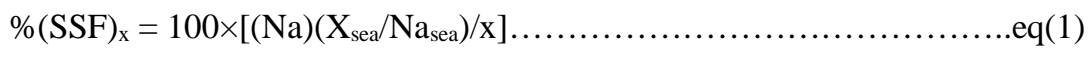

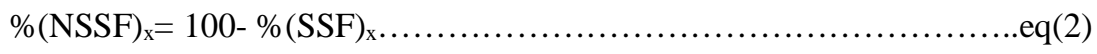

Where $\mathrm{x}$ is the ion concentration as measured in the dew, $\mathrm{X}_{\text {sea }}$ is the concentration of ion in sea water, and $\mathrm{Na}_{\text {sea }}$ is the concentration of the Na reference ion in sea water. Results of calculations as demonstrated in Table.2 indicated that all ions except for $\mathrm{Mg}^{2+}(\%(\mathrm{SSF}) \mathrm{x}=52.71)$ and $(90 \%$ of the samples $) \mathrm{Cl}^{-}(\%(\mathrm{SSF}) \mathrm{x}=164)$ are coming from non-sea-salt fraction or continental Sahara dust origin, which is true since Amman city is located around $400 \mathrm{Km}$ north of Gulf of Aqaba and Arabian desert and around $200 \mathrm{Km}$ east of the Mediterranean sea; enabling some vapor sea salts relocation and carrying over to Amman by Sahara wind coning from the south. The correlation of the present study data with that previously reported in Morocco (Lekouch et al. 2011) indicated strongly that dust deposition with dew is equivalence to

\section{< Fig.1>}


dew formation at very dry conditions as indicated in Fig. 2 with the exception of very high concentrations of $\mathrm{Na}^{+}$and $\mathrm{Cl}^{-}$ ions that are exceeding the $\mathrm{ca}^{2+}$ concentration and are coming from the ocean (sampling site $200 \mathrm{~m}$ from ocean).

The presence of silica and boron in the dew-dust deposits is also a strong indication for the involvement of dust constituents in the dew chemical composition where in general boron and silica exist in natural waters with varying concentrations depending on the geochemical nature but if they exist in air they come from anthropogenic sources (WHO/SDE/WSH/03.04/54). The boron concentrations where in the range of $1.27 \mathrm{mg} / \mathrm{L}$ to $1.92 \mathrm{mg} / \mathrm{L}$ with a mean value of $1.48 \mathrm{mg} / \mathrm{L}$ exceeding the standard value which is $0.3 \mathrm{mg} / \mathrm{L}$ for drinking water as indicated in Table.1.

\section{< Fig.2>}

\subsection{Total organic carbon (TOC)}

The measured TOC values ranged from 11.86 to $74.60 \mathrm{mg} / \mathrm{L}$ with an average value of $24.30 \mathrm{mg} / \mathrm{L}$ indicating the presence of high concentrations of dissolved organic matter that could be related to volatile organic compounds (VOCs) that were washed out due to dew formation or semi-volatiles that are adsorbed on the aerosols or particulate matter where some of these organics are harmful and may be carcinogenic (Ervens et al. 2013). The measured values are exceeding the reported results from fog and clouds study (Ervens et al. 2013) where results ranged from 5.9 to $27 \mathrm{mgC} \mathrm{L}^{-1}$ with a mean value of $12.6 \mathrm{mgC} \mathrm{L}^{-1}$. Also the TOC values in our study are exceeding values in surface and drinking waters from the White River in Muncie (Indiana) (Volk et al. 2002); where TOC values ranged from $2.15-11.90 \mathrm{mgC} \mathrm{L}^{-1}$ with average value of $4.00 \mathrm{mgC} \mathrm{L}^{-1}$. The high TOC values affects the quality of the collected dew-dust water even after filtration as a potable source of water for its acrid taste and exceeding the limits of the Jordanian Drinking Water standards/ WHO for drinking water (TOC $<2 \mathrm{mg} / \mathrm{L})$. Also it is worth mentioning that many studies in literature (Dubber et al. 2010; Nutt et al. 2013) reported models that correlates the values of the TOC with those of $\mathrm{BOD}_{5}$ (biological oxygen demand for five days) values such as the one reported by the North End Pollution Control Center (NEWPCC) for the city of Winnipeg, Canada (TOC= $\left.0.5569\left(\mathrm{BOD}_{5}\right)+11.38\right)$, where TOC is measured and $\mathrm{BOD}_{5}$ is calculated to save time and money. Where the $\mathrm{BOD}_{5}$ is an important parameter that determines the quality of raw treated water or effluents of wastewater. In our case the average TOC value was $24.30 \mathrm{mg} / \mathrm{L}$ where this value in terms of $\mathrm{BOD}_{5}$ is expected to exceed the standard limits for $\mathrm{BOD}_{5}$ in drinking water according to the Jordanian Drinking Water standards (JS 286/1997)/WHO standard (BOD 5 is not specified or required) but comes in the range of the $\mathrm{BOD}_{5}$ for reused water for agriculture and effluents of treated water $\mathrm{BOD}_{5}<$ $60 \mathrm{mg} / \mathrm{L}$ (Irrigation Water Quality Guidelines -December 2006).

\section{Conclusion}

The dew collection with dust precipitates without pre-treatment or cleaning of the collecting surface allowed dust to be involved and affected dramatically the chemical composition of dew water. Mean pH values of 7.35 and high values for total mineralization, total hardness, TOC, presence of particulate settled material, and presence of undesired elements like boron made it different in properties from other dew water collections at clean surfaces. The origin of the major cationic species $\mathrm{Ca}^{2+}$, and anionic species $\mathrm{SO}_{4}{ }^{2-}$ was related to the continental Sahara dust. This mandates a pretreatment or multiple filtrations (simply combined sand filter and activated charcoal filter costing around 30 \$US) for the dew water if it is planned to be used as potable source of water; otherwise it can be used for agriculture. To our knowledge the obtained results regarding this approach of collecting the dew water is not reported the literature. 


\section{Acknowledgement}

This study was supported by the Deanship of Scientific Research at the University of Jordan, University of

Petra, Al Zaytoonah University of Jordan, and the Academy of Finland Center of Excellence (Grant No. 272041)

\section{$\underline{\text { References }}$}


Agam N, Berliner PR (2006) Dew formation and water vapour adsorption in semi-arid environments- a review. J. Arid Environ 65: 572-590

AL-Momani IF, Momani KA, Jaradat QM (2000) Chemical composition of wet precipitation in Irbid, Jordan. J. Atmos Chem 35 (1): 47-57

Alnaser WE, Barakat A (2000) Use of condensed water vapour from the atmosphere for irrigation in Bahrain. Appl. Energy 65(1-4): 3-18.

Beysens D (1995) The formation of dew. Atmos Res 39: 215-237.

Beysens D (2006) Dew nucleation and growth. C R Phys 7(9-10): 1082-1100

Beysens D, Clus O, Mileta M, Milimouk I, Muselli M, Nikolayev VS (2007). Collecting dew as a water source on small islands: the dew equipment for water project in (Croatia) Energy 32: 1032-1037.

Beysens D, Museli, M. I., Ohayone, C., Berkowicz, S.M., Soyeuxg, E., Mileta, M., Ortega, P (2006) Application of passive radiation cooling for dew condensation. Energy 31, 1967-1979.

Beysens D, Ohayon C, Muselli M, Clus O (2006). Chemical and bacterial characteristics of dew and rain water in an urban coastal area (Bordeaux, France). Atmos Environ 40(20): 3710-3723

Degen AA, Leeper A, Shachak M (1992) The effect of slope direction and population-density on water influx in a desert snail, Trochoidea seetzenii. Funct Ecol 62: 160-166

Dubber D, Gray NF (2010) Replacement of chemical oxygen demand (COD) with total organic carbon (TOC) for monitoring wastewater treatment performance to minimize disposal of toxic analytical waste. J Environ Sci Heal A 45(12): 1595-600.

Ervens B, Wang Y, Eagar J, Leaitch W R, Macdonald A M, Valsaraj, KT, Herckes P ( 2013) Dissolved organic carbon (DOC) and select aldehydes in cloud and fog water: the role of the aqueous phase in impacting trace gas budgets. Atmos Chem Phys 13: 5117-5135.

Foster JR, Pribush RA, Carter BH (1990) The chemistry of dews and frosts in Indianapolis, Indiana. Atmos Environ 24(A): 2229-2236

Galek G, Sobik M, Blas M, Polkowska Z, Cichala-Kamrowska K (2012) Dew formation and chemistry near a motorway in Poland. Pure Appl Geophys 169: 1053-1066.

Gałek G, Sobik M, Błaś M, Polkowska Ż, Cichała-Kamrowska K, Wałaszek, K.( 2015) Dew and hoarfrost frequency, formation efficiency and chemistry in Wroclaw, Poland. Atmos Res 151: 120-129.

Ganor E (1991) The composition of clay minerals transported as indicators of Saharan dust emission. Atmos Environ Part A 25(12): 2657-2664

Guadarrama-Cetina J, Mongruel A, Medici MG, Baquero E., Parker AR, Milimouk-Melnytchuk I, Gonz’alez-Vi nas W, Beysens D (2014) Dew condensation on desert beetle skin. Eur Phys J E 37: 109

Irrigation Water Quality Guidelines (2006) Gtz Jordanian- German Water program. http://www.jva.gov.jo/sites/enus/Documents/Pilot\%20Project/IWQGL\%202006_english_version.pdf.

Jaradat Q, Momani K, Jiries A, El-Alali A, Batarseh M, Sabri T, Al-Momani I (1999) Chemical composition of urban wet deposition in Amman, Jordan. Water Air Soil Poll 112: 55-65

Jiries A (2001) Chemical composition of dew in Amman, Jordan. Atmos Res 57: 261-268.

Keene WC, Pszenny AP, Galloway JN, Hawley ME (1986) Sea salt corrections and interpretations of constituent ratios in marine precipitation. J Geophys Res 91: 6647-6658

Lekouch I, Mileta M, Muselli M, Milimouk-Melnytchouk I, Šojat V, Kabbachi B, Beysens D (2010) Comparative chemical analysis of dew and rain water. Atmos Res 95: 224-234.

Lekouch I, Muselli M, Kabbachi B, Ouazzani J, Melnytchouk-Milimouk I, Beysens D (2011) Dew, fog, and rain as supplementary sources of water in south-western Morocco. Energy 36: 2257-2265.

Menenti M, Bastiaanssen, WGM, Van-Eick D (1989) Determination of surface hemispherical reflectance with Thematic Mapper data. Remote Sens Environ 28: 327-337.

Minnis P, Mayor, S, Smith WL, Young DF (1997) Asymmetry in the diurnal variation of surface albedo. IEEE Trans Geosci Remote Sens 35(4): 879-891.

Moffett MW(1985) An Indian ant's novel method for obtaining water. National Geographic Research 1(1): 146-149

Morin L, Auld BA, Brown JF(1993) Host range of Puccinia xanthii and postpenetration development on Xanthium occidentale. Can J Bot 71 7: 959-965

Muselli M, Beysens D, Soyeux E (2006) Is dew water potable? Chemical and biological analyses of dew water in Ajaccio Corsica Island, France. J Environ Qual 35(5): 1812-1817.

Nilsson T, Vargas W, Niklasson G, Granqvist C (1994) Condensation of water by radiative cooling. Renew Energ 5(1): 310-317 
Nutt SG, \& Tran J of XCG Consultants Ltd (2013) Addressing BOD5 limitations through Total Organic Carbon Correlations: A Five Facility International Investigation. An Instrumentation Testing Water \& wastewater Association for North America (ITA) research \& development report. http://www.instrument.org/ePubs/PubContents/RDR13TOC-Table Of Contents.pdf. Accessed January 2013.

Wagner G, Steel K, Peden ME (1992) Dew and frost chemistry at a Midcontinent site, United States. J Geophys ResAtmos 97: 20591-20597.

Okochi H, Kataniwa M, Sugimoto D, Igawa M (2005) Enhanced dissolution of volatile organic compounds into urban dew water collected in Yokohama, Japan. Atmos Environ 39: 6027-6036.

OPUR. Organization Pour l' Utilization de la Rosee .http://www.opur.fr/

Pedro MJ, Gillespie TJ(1982) Estimating dew duration. I. Utilizing micrometeorological data. Agric Meteorol 25: 283296.

Polkowska Ż, Błaś M, Klimaszewska K, Sobik M, Małek S, Namieśnik J(2008) Chemical characterization of dew water collected in different geographic regions of Poland. Sensors 8: 4006-4032.

Rice EW, Baird RB, Eaton AD, Clesceri LS (2012) American Public Health Association. American Water Works Association., \& Water Environment Federation. Standard Methods for the Examination of Water and Wastewater. Washington, DC: American Public Health Association.

Shachak M, Leeper A, Degen AA (2002) Effect of population density on water influx and distribution in the desert snail Trochoidea seetzenii. Ecoscience 9 (3): 287-292

Singer A, Shamay Y, Fried M (1993) Acid rain on Mt Carmel, Israel. Atmos Environ 27(A): 2287-2293

Takeuchi M, Okochi H, Igawa M (2002) Controlling factors of weak acid and base concentrations in urban dewatercomparison of dew chemistry with rain and fog chemistry. Bull Chem Soc Jpn 75: 757-764.

Thomas JFJ, \& Lynch JJ (1960) Determination of carbonate alkalinity in natural waters. J Am Water Works Assoc 52: 259

Volk C, Wood L, Johnson B, Robinson J, Zhu HW, Kaplan L (2002)Monitoring dissolved organic carbon in surface and drinking waters. J Environ Monitor 4: 43-47

Vuollekoski H, Vogt M, Sinclair V A, Duplissy J, Järvinen H, Kyrö EM, Makkonen R, Petäjä T, Prisle N L, Räisänen P, Sipilä M, Ylhäisi J, Kulmala M(2015). Estimates of global dew collection potential on artificial surfaces. Hydrol Earth Syst Sci 19: 601-613.

WHO/SDE/WSH/03.04/54 (2003) Boron in Drinking-water, Background document for development of WHO Guidelines for Drinking-water Quality. http://www.who.int/water_sanitation_health/dwq/boron.pdf

Yaalon DH, Ganor E(1968) Chemical composition of dew and dry fallout in Jerusalem, Israel. Nature 217: 1139-1140

Zangvil A (1996) Six years of dew observations in the Negev Desert, Israel. J Arid Environ 32: 361-371

Zhang W, Watson AK(1997) Host range of Exserohilum monoceras, a potential bioherbicide for the control of Echinochloa species. Can J Bot 75 (5): 685-692 
Table 1: Aqueous dew-dust precipitate samples chemical composition minimum, maximum and mean concentrations

\begin{tabular}{|c|c|c|c|c|}
\hline Sample/Test & Min & Max & Mean & $\begin{array}{l}\text { Jordanian Drinking Water standards (JS } \\
\text { 286/1997) based on WHO guidelines }\end{array}$ \\
\hline Volume collected $(\mathrm{mL})$ & 22 & 230 & 119.87 & $\ldots \ldots$ \\
\hline $\mathrm{pH}$ & 6.90 & 8.17 & 7.35 & $6.5-8.5$ \\
\hline Bicarbonate $\left(\mathrm{HCO}_{3}{ }^{-}\right)(\mathrm{mg} / \mathrm{L})$ & 105.6 & 266.00 & 181.5 & $*$ \\
\hline Turbidity (NTU) & 20.1 & 520 & 192.23 & $<1-5$ \\
\hline $\mathrm{Na}^{+}(\mathrm{mg} / \mathrm{L})$ & 5 & 24 & 15.02 & $<200-400$ \\
\hline $\mathrm{K}^{+}(\mathrm{mg} / \mathrm{L})$ & $<\mathrm{LRV}$ & 5.32 & 2.66 & $*$ \\
\hline $\mathrm{Ca}^{2+}(\mathrm{mg} / \mathrm{L})$ & 38 & 89 & 59 & $*$ \\
\hline $\mathrm{Mg}^{2+}(\mathrm{mg} / \mathrm{L})$ & 0.5 & 11.4 & 3.85 & * \\
\hline Hardness as $\mathrm{CaCO}_{3}(\mathrm{mg} / \mathrm{L})$ & 154 & 233 & 166 & $<100-500$ \\
\hline $\mathrm{F}^{-}(\mathrm{mg} / \mathrm{L})$ & $<\mathrm{LRV}$ & 0.58 & 0.34 & 1.5 \\
\hline $\mathrm{Cl}^{-}(\mathrm{mg} / \mathrm{L})$ & 7 & 44 & 16.17 & $<200-500$ \\
\hline $\mathrm{SO}_{4}{ }^{2-}(\mathrm{mg} / \mathrm{L})$ & 8 & 48 & 26.71 & $<200-500$ \\
\hline silicate $(\mathrm{mg} / \mathrm{L})$ & 11.80 & 15.39 & 12.45 & $*$ \\
\hline $\mathrm{NO}_{3}{ }^{-}$as nitrate $(\mathrm{mg} / \mathrm{L})$ & $<\mathrm{LRV}$ & 11.23 & 5.02 & $<50-70$ \\
\hline Boron $(\mathrm{mg} / \mathrm{L})$ & 1.27 & 1.92 & 1.48 & 0.3 \\
\hline $\begin{array}{l}\text { Electrical conductivity }(\mathrm{EC}) \\
(\mu \mathrm{s} / \mathrm{cm})\end{array}$ & 233 & 1305 & 613.17 & * \\
\hline $\begin{array}{l}\text { Total dissolved solids } \\
(\mathrm{TDS})(\mathrm{mg} / \mathrm{L})\end{array}$ & 160 & 835 & 286.71 & $<500-1500$ \\
\hline $\begin{array}{l}\text { Total Organic Carbon (TOC) } \\
(\mathrm{mg} / \mathrm{L})\end{array}$ & 11.86 & 74.60 & 24.30 & $<2 \mathrm{mg} / \mathrm{L}$ (preferred) \\
\hline
\end{tabular}

$\mathrm{LRV}=$ Factor*MDL, where the factor is up to $5 . \mathrm{LRV}$ for $\mathrm{NO}_{3}{ }^{-}=0.5 \mathrm{mg} / \mathrm{L}$, for $\mathrm{K}^{+}=1 \mathrm{mg} / \mathrm{L}$, and for $\mathrm{F}^{-}=0.2 \mathrm{mg} / \mathrm{L}$. where MDL stands for method detection limit.* stands for not specified. 
Table 2: $\%(\mathrm{SSF})_{\mathrm{X}}$ and $\%(\mathrm{NSSF})_{\mathrm{X}}$ for dew-dust precipitates samples and sea water

\begin{tabular}{|l|l|l|l|l|l|}
\hline Ion & $\begin{array}{l}\text { Average concentration } \\
(\mathrm{meq} / \mathrm{L}\end{array}$ & Dew water ion ratio & Sea water ratio & $\%(\mathrm{SSF})_{\mathrm{X}}$ & $\%(\mathrm{NSSF})_{\mathrm{X}}$ \\
\hline $\mathrm{Ca}^{2+}$ & 2.90 & 4.46 & 0.044 & 0.99 & 99.01 \\
\hline $\mathrm{Mg}^{2+}$ & 0.31 & 0.48 & 0.227 & 47.29 & 52.71 \\
\hline $\mathrm{K}^{+}$ & 0.07 & 1.11 & 0.022 & 1.98 & 98.02 \\
\hline $\mathrm{Cl}^{-}$ & 0.46 & 0.71 & 1.166 & 164 & 0.00 \\
\hline $\mathrm{SO}^{2-}$ & 0.56 & 0.86 & 0.04 & 4.65 & 95.35 \\
\hline $\mathrm{NO}_{3}^{-}$ & 0.35 & 0.54 & 0.00002 & 0.004 & 99.97 \\
\hline
\end{tabular}

